\title{
Cosplay dan Idola Remaja Medan (Studi Kajian Budaya Tentang Mimikri)
}

\author{
M. Reno Pakusadewo
}

\begin{abstract}
Abstrak
Artikel ini mengkaji tentang Komunitas Cosplayer di kota Medan, Subjek cosplay atau cosplayer pada dasarnya berangkat dari suatu fenomena yang terjadi di Jepang dan menyebar luas melalui media dan akhirnya menjadi sangat popular di banyak Negara. Fenomena ini terjadi dikarenakan juga adanya hubungan antara fenomena yang terjadi dengan suatu bentuk kepribadian individu. Tujuan penelitian ini adalah Untuk mengetahui sejarah dan tujuan awal terbentuknya komunitas cosplay di kota Medan dan untuk mengetahui latar belakang cosplayer masuk dalam komunitas cosplay di kota Medan Penelitian ini menggunakan metode penelitian kualitatif dan analisa data dilakukan dengan menggunakan analisa deskriptif kualitatif, yaitu untuk mempelajari dan mendeskripsikan sifat-sifat yang khas dari suatu fenomena sosial tertentu secara sistematis. Teknik pengumpulan data melalui pengamatan (observasi), wawancara dan diperkaya dengan studi kepustakaan. Hasil penelitian ini, Pola cosplayer yang memulai cosplay karena dengan ber-cosplay, cosplayer dapat menikmati kesenangan dari memerankan diri yang berbeda dari dirinya sehari-hari.Pola cosplayer yang memulai cosplayer karena kecintaannya terhadap karakter anime, manga dan sebagainya, ber-cosplay dengan berpenampilan yang sama dengan karakter yang ia sukai tersebut.Pola cosplayer yang belum tentu memiliki ketertarikan pada anime dan game, tetapi memulai cosplay karena ajakan teman. Dan dampak lingkungan Cosplayer terhadap keluarga faktor penghambat cosplayer untuk menyalurkan hobi, menambah teman sehobi, mengisi waktu luang dan untuk senang senang. Serta, hasil penelitian ini juga menunjukkan pengaruh-pengaruh kegiatan-kegiatan cosplay yang bermacam-macam terhadap cosplayer itu sendiri, karena cosplayer hanyalah menjadi cosplayer ketika adanya kegiatan cosplay tersebut. Kata Kunci: cosplay, mimicry culture, idola remaja
\end{abstract}




\section{Pendahuluan}

Menurut Koentjaraningrat $(2000 ; 9)$ kebudayaan dengan kata dasar budaya berasal dari bahasa Sansekerta "buddhayah" yaitu bentuk jamak dari buddhi yang berarti "budi" atau "akal". Jadi Koenjaraningrat mendefinisikan budaya sebagai "daya budi" yang berupa cipta, karsa dan rasa, sedangkan kebudayaan adalah hasil dari cipta, karsa dan rasa itu. Di era globalisasi ini, setiap kebudayaan luar dapat dengan mudah masuk ke Indonesia, akan tetapi setiap budaya yang masuk harus disaring terlebih dahulu layak atau tidaknya berkembang di negri kita. Perkembangan yang begitu pesat membawa banyak perubahan, salah satunya pada gaya hidup, lewat media yang ada seperti televisi, dan internet serta berpengaruh kepada norma dan prilaku.

Banyak Negara yang memperkenalkan kebudayaannya masuk ke Indonesia seperti budaya Barat, Cina, Korea, dan Jepang. Di sini penulis ingin membahas salah satu budaya Jepang yang sangat diminati oleh remaja di Indonesia, demam budaya Jepang di Indonesia membuat remaja-remaja di Indonesia membentuk sebuah komunitas budaya Jepang di Indonesia. Harajuku style istilah yang sering di gunakan atau sebutan untuk gaya berpakaian dan gaya rambut bagi komunitas budaya Jepang, yang sering berkumpul di harajuku yang berbatasan dengan Shinjuku dan Shibuya yang merupakan salah satu area pusat keramain di Tokyo, Jepang.

Daerah tersebut merupakan tempat berkumpulnya anak - anak muda Jepang yang ingin mengekspresikan hobinya.Dandanan yang nyentrik dengan rambut yang asimetris dan pakaian yang cendrung warna mencolok, menjadi ciri khas harajuku style, pada umunya mereka mengidentifikasikan diri dalam karakter anime, penyanyi punk rock, dan sebainya. Harajuku style terbagi atas beberapa gaya yaitu visual kei, Lolita, ganguro, dan cosplay. Peneliti mengkhususkan unuk meneliti mengenai komunitas coplay.

Cosplay (コスプレKospure ) adalah gabungan dari "coustume" (kostum) dan "play" (bermain). Cosplay hobi mengenakan pakaian serta aksesoris dan rias wajahseperti yang di kenakan dalam tokoh - tokoh anime, manga, dongeng, game, dan film kartun. Pelaku cosplay disebut cosplayer, di kalangan penggemar cosplayer disebut juga sebagai coser. Pada mulanya budaya ini dilakukan oleh orang - orang barat yang memakai kostum atau pesta topeng di hari - hari perayaan besar seperti Easterdan Halloween. Kemudian tradisi ini sampai kejepang pada tahun 1978 dalam pertemuan konvenksi fiksi ilmiah, cosplay merupakan semacam pertemuan atau sekelompok orang yang merupakan penggemar anime atau manga, yang 
dilakukan oleh individu - individu yang membuat dan berdandan menggunakan kostum tertentu dari sebuah karakter anime ataupun manga untuk tampil pada acara tertentu maupun pada festival.

Kaum remaja di Indonesia menerima dengan baik budaya popular Jepang yang satu ini. Khususnya kaum remaja yang berada di Medan. Penggemar cosplay di Medan terus menjamur yang sekaligus ditandai dengan terbentuknya sejumlah komunitas cosplay yang dikenal dengan Cosplay Medan. Mereka menirukan sosok anime dengan berdandan dan menggunakan kostum tertentu dari sebuah karakter anime.Cosplayer senior Medan, Michitsuna, mengatakan komunitas ini memang wadah bagi mereka yang ingin terus beraktivitas dan menyalurkan hobinya di dunia cosplay. Sejak terbentuk 2010 silam komunitas ini masih terus aktif mulai dari hanya sekedar kumpul bareng hingga mengikuti berbagai lomba. Ini bukan komunitas berbasis organisasi jadi kami kumpul atau beraktifitas kalau lagi ada acara atau memang keinginan para anggota, saat ini perkembangan cosplay di Medan masih baik, terbukti dengan sudah semakin banyaknya berbagai jenis kostum anime Jepang serta ditandai pula banyaknya masyarakat dari selurul lapisan masyarakat yang mulai menggeluti cosplay. Anggota komunitas ini pun setiap tahunnya bertambah yang kini sudah berjumlah 80 orang. Selain itu di dalam komunitas Cosplay Medan juga masih banyak sub grup lain yang dikarenakan memang tujuan awal dibentuknya komunitas ini agar semua saling kenal dan menambah pertemanan, karena mengingat cosplay ini akan terus berkembang jadi tidak boleh tertinggal satu sama lain tuturnya (Tanjung Arianda; Cosplay Medan; kWaspada, 31 Juli 2016).

Dari hasil observasi yang dilakukan di Ringroad City Walk Medan, diketahui informasi dari anggota cosmed menjelaskan bahwa,dalam keseharian anggota cosplay di Medan dari segi pakaian anggota komumunitas cosplay tidak sepenuhnya memakai kostum anime, mereka lebih memakai pakaian/ blouse seperti biasanya dan mereka memakai kostum anime disaat event-event tertentu saja. Selanjutnya dari segi riasan wajah, anggota cosplay tidak sepenuhnya memakai riasan wajah yang bertemakan tokoh anime dalam kehidupan sehari-hari. Kemudian dari segi bahasa, mereka tidak sepenuhnya memakai bahasa Jepang. Dalam Kamus Besar Bahasa Indonesia (KBBI). Komunitas adalah sekumpulan kelompok orang yang saling berinteraksi memiliki minat dan ketertarikan yang sama dengan penggemar lainya. Dalam komunitas seseorang dapat dengan bebas mengungkapkan kesukaannya dan merasa di terima apa adanya di 
sebuah komunitas tersebut karena masing - masing memiliki minat yang sama dengan satu dan yang lainnya (http://kbbi.web.id/komunitas)

Umumnya cosplayer memakai kostum mereka di sebuah acar kompetisi cosplay, pertunjukan busana atau pengambilan foto. Kompetisi dalam pertunjukan pendek yang melibatkan pengikut acara benar - benar berakting menyerupai karakter yang diperankan dan mereka sangat menikamati ketika difoto dengan memakai kostum. Mimikri dalam studi poskolonialisme dan secara khusus dalam pandangan Bhabha (1994) adalah "reproduksi belangbelang subjektivitas eropa di lingkungan kolonial yang sudah "tidak murni", tergeser dari asalusulnya dan terkonfigurasi ulang dalam cahaya sensibilitas dan kegelisahan kolonialisme dan menjelaskan bahwa operasi mimikri tersebut yang dilakukan oleh pihak penjajah maupun terjajah, menghasilkan efek-efek yang ambigu dan kontradiktif dengan demikian, dapat dikatakan bahwa hasil dari mimikri selalu "hampir serupa tapi tetap tidak sama". Hasil dari mimikri yang demikian adanya disebabkan oleh upaya otoritas kolonial yang terus berusaha mengendalikan dengan ketat peniruan yang dilakukan oleh pihak terjajah. Pengendalian itu adalah membatasi peniruan kondisi mimikri ini adalah sebuah pilihan yang diberikan Bhabha sebagai pilihan psikis yang dihadapi oleh kawula-kawula kolonialisme(Bhabha 1994;).

Karina Aisyah (2012), mahasiswa Fakultas IImu Penegetahuan Budaya Program Studi Jepang Universitas Indonesia ( UI ), dalam skripsinya yang berjudul "Rasa Memiliki dalam Komunitas Cosplay" menjelaskan rasa memiliki merupakan rasa terhubung dan diterima dalam sebuah keluarga atau komunitas. Seseorang dapat merasakan rasa memiliki ini ketika didalam sebuah keluarga atau komunitas yang menerimanya, salah satu tersebut adalah komunitas penggemar yaitu adalah fandom.Fandom merupakan penggemar antusias dan memiliki ketertarikan terhadap hal yang sama, fandom menawarkan ruang untuk komunitas yang memungkinkan orang-orang dengan latar belakang dan pengalaman yang beragam membentuk ikatan diseputar minat yang sama. Dalam fandom anime dan manga terdapat komunitas kecil yaitu cosplay yang dimana memberikan ruang kepada penggemar untuk mengekspresikan diri mereka yang sebenarnya. Komunitas seperti ini membuat para penggemar tahu bahwa mereka tidak sendirian dalam kegemaran dan minat mereka.

Meirisyah Eldinah (2012) mahasiswa Pendidikan Antropologi Fakultas IImu Sosial Universitas Negri Medan (UNIMED), dalam skripsinya yang berjudul "Profil tiga Cosplayer Pada Komunitas Sebagai Pembentuk 
Identitas diri Remaja" menjelaskan cosplay merupakan suatu kegiatan koustum karakter yang berasal dari manga, anime, dan game. Dari koustum yang di perankan harus tampil semirip mungkin.Orang yang memakai koustum sesuai dengan karakternya disebut cosplayer, awal mulanya seorang cosplayer karena hobi membaca manga, menonton anime dan terkadang seorang cosplayer terbawa bawa dalam kehidupan mereka sehari-hari. Biaya yang di keluarkan untuk hobi cosplay tidak sedikit sehingga orang lain tidak memahami hobi ini menganggap hanya buangbuang uang dan waktu saja.

Riatifani Sukma Pratiwi (2012) mahasiswa Program Studi Psikologi Fakultas IImu Sosial dan IImu Politik Universitas Mulawarman, dalam skripsinya yang berjudul "Faktor Penyebab Perilaku Cosplayer LARP (Live Action Role Playing) Anime Pada Komunitas JCEB ( Japanese Club East Borneo) Samarinda, menjelaskan JCEB ( Japanese Club East Borneo) merupakan salah satu komunitas Jepang yang berpusat di Samarinda komunitas ini terbentuk pada tanggal 10 Desember 2009 yang dilatar belakangi oleh kecintaan terhadap kebudayaan jepang mulai dari musik, manga, anime, hingga cosplay. Komunitas JCEB sering berpartisipasi dalam berbagai even di kota-kota besar seperti Bontang dan Balikpapan anggota dari komunitas ini beragam usia mulai dari anak-anak samapai dewasa yang kemudian mereka menggunakan kostum dan melakukan pemotretan.

Yustina Barimbing (2012) mahasiswa Profta Studi DIII Bahasa Jepang Fakultas IImu Budaya Universitas Sumatera Utara, dalam skripsinya yang berjudul "Cosplay Jepang Nihon No Kosupure" menjelaskan mengenai fashion style Jepang di kalangan remaja khususnya di wilayah kota Medan, dalam skripsinya Yustina Barimbing juga menjelaskan bahwa seorang cosplayer rela melakukan apapun untuk mendapatkan hasil yang sempurna saat berperan menjadi salah satu tokoh yang mereka perankan dan tidak jarang mereka sering melakukan pertukaran peran seperti wanita memerankan peran seorang pria, bahkan mereka terkadang juga melakukan penurunan berat badan (diet), berganti - ganti warna rambut secara terusmenerus. Hal ini dilakukan selain karna suka terhadap karakter tersebut, juga karena mereka mampu memerankan karakter tersebut dan demi memerankan sebuah tokoh yang semaksimal mungkin. Ada beberapa persamaan terdapat pada penelitian Karina Aisyah, Meirisyah Eldinah, Riatifani Sukma Pratiwi, Yustina Barimbing dengan penelitian yang akan peneliti lakukan terkait dengan objek dan kasus penelitian yang sama-sama meneliti tentang komunitas cosplay. Sementra perbedaannya terletak pada 
lokasi penelitian dan fokus penelitian. Adapun perbedaan penelitian yang penulis lakukan dengan Karina Aisyah (2012) terletak pada lokasi penelitian dan fokus penelitian. Karina Aisyah menjelaskan rasa memiliki merupakan rasa terhubung dan diterima dalam sebuah keluarga atau komunitas, salah satunya yaitu komunitas fandom. Sedangkan penelitian yang di lakukan penulis meneliti komunitas cosplay di kota Medan.

Penelitian Meirisyah Eldinah (2012), dengan penulis lakukan mempunyai lokasi penelitian yang sama yaitu di kota Medan, akan tetapi fokus penelitian berbeda Meirisyah Eldinah hanya melihat tiga profil cosplayer sedangkan penelitian yang penulis lakukan meneliti komunitas cosplay di kota Medan. Penelitian Riatifani Sukma Pratiwi (2012), dengan penelitian yang penulis lakukan mempunyai perbedaan lokasi penelitian. Riatifani Sukma Pratiwi melakukan penelitian di samarinda pada komunitas JCEB ( Japanese Club East Borneo) serta perilaku yang di timbulkan oleh anggota cosplay dan apa saja yang mempengaruhi para cosplyer. Sedangkan penulis melakukan penelitian di Kota Medan pada komunitas cosplay, serta peneliti juga membahas sejarah dan latar belakang terbentuknya komunitas cosplay. Penelitian yang dilakukan Yustina Barimbing (2012) dan peneliti, memiliki lokasi penelitian yang sama. Perbedaannya terletak dari segi pengumpulan data dimana Yustina melakukan pengumpulan data secara library research sedangkan peneliti melakukan pengumpulan data secara kualitatif.

\section{Metode Penilitian}

Penelitian ini dilakukan di Kota Medan yang merupakan salah satu wilayah kota di Provinsi Sumatera Utara, khususnya pada komunitas cosplay di kota Medan (cosmed) yang sering mengadakan event - event dan ikut sert dalam event yang di selnggarakan di kota Medan. Yang umunya sering di lakukan di kalangan remaja, terutama pada mahasiswa sastra Jepang di Universitas Sumatera Utara. Dalam penelitian ini penulis melakukan metode penelitian kualitatif yang bersifat deskritif mengenai "Komunitas Cosplay di Kota Medan" dan di dukung dengan pendektan penelitian etnografi. Wawancara dilakukan langsung ke peserta Cosplay yang menjadi fokus penelitian. Observasi dilakukan dalam setiap acara Cosplay yang dilakukan di Kota Medan.

\section{Perkembangan Cosplay di Kota Medan}

Folk yang sama artinya dengan kata kolektif, menurut Alan Dundes, folk adalah sekelompok orang yang memiliki ciri pengenalan fisik, sosial, dan 
kebudayaan, sehingga dapat dibedakan dari kelompok-kelompok lainya. Namun yang lebih penting lagi adalah bahwa mereka telah memiliki suatu tradisi, yakni kebudayaan yang telah mereka warisi turun-menurun (James Danandjaya, 1991 :1). Setiap bangsa di dunia ini umumnya mempunyai permainan rakyat.Kegiatan ini juga termasuk folklor karena diperolehnya melalui warisan lisan, karena permainan ini disebarkan hampir melalui tradisi lisan.Permainan rakyat di dunia ini, untuk orang dewasa maupun anak-anak, biasanya berdasarkan gerak tubuh seperti lari, lompat, atau berdasarkan kegiatan sosial sederhana seperti kejar-kejaran, sembunyi-sembunyian dan berkelahi.

Cosplay adalah salah satu kebudayaan Jepang yang termasuk dalam bentuk foklor yang disebut permainan rakyat yang umumdi mainkan oleh kaum remaja di Jepang, yang kini menjadi sangat populer diberbagai tempat dibelahan dunia terutama di Indonesia khususnya di Kota Medan. Cosplay sendiri gabungan dari bahasa Inggris Coustume dan Play yang berarti bermain dengan kostum, umunya cosplay sangat identik dengan riasanriasan dan kostum yang diperankan oleh tokoh anime dan mangaAnime adalah animasi khas Jepang, yang biasanya dicirikan melalui gambargambar berwarna-warni yang menampilkan tokoh-tokoh dalam berbagai macam lokasi dan cerita, yang ditujukan pada beragam jenis penonton.Manga merupakan komik yang dibuat di Jepang, kata tersebut digunakan khusus untuk membicarakan tentang komik Jepang, sesuai dengan gaya yang dikembangkan di Jepang.Seorang pelaku cosplay disebut juga dengan cosplayer atau bisa disebut juga coser.

Perkembangan cosplay di Kota Medan khususnya dikalangan remaja sudah tidak asing lagi, di mana sebelumnya, para remaja yang ada di Kota Medan mengenal cosplay melalui berbagai media, baik majalah-majalah, televisi, internet, maupun dari berbagai media sosial lainya. Awalnya mulanya cosplay di kenal dikalangan remaja Medan melalui kegiatan Bukansai, yang di selenggarakan oleh mahasiswa Jurusan Sastra Jepang Universitas Sumatera Utara dalam pelaksanaan kegiatan tahunan "Festival Budaya Jepang" (Bukansai) pada tahun 2008.

Adapun salah satu kegiatannya yaitu mengadakan kegiatan ber-cosplay untuk memeriahkan kegiatan tersebut.Perlombaan ber-cosplay di selenggarakan karena dianggap oleh panitia pelaksana sangat berhubungan dengan kegiatan di kalangan remaja Jepang.Pada tahun pertama, perlombaan yang di selenggarakan sangat sederhana, yaitu seorang 
cosplayer yang mengikuti perlombaan hanya sekedar melakukan peragaan berjalan di atas panggung, layaknya seorang model. Yang dimana seharusnya makna cosplay itu sendiri berarti nmemperagakan karakter tokoh anime atau manga dan lainya diiringin musik (sound) atau suara sesuai dengan karakter yang diperankan. Secara sederhana cosplayers membantah bahwa mereka tidak sama dengan model atau aktor.

Perkembangan paling pesat terjadi pada tahun 2010 sejak diperkenanalkan oleh Universitas Negeri yang ada di Medan. Banyak acara lomba cosplay yang telah digelar dikota Medan. Salah satu acara cosplay terkini adalah perlombaan cosplay yang digelar di Hermes Place Polonia, Medan pada hari sabtu tanggal 22 maret 2014. Perlombaan cosplay ini merupakan salah satu upaya pemeritah Kota Medan untuk mendorong kampanye kebersihan dikota Medan dalam rangka promosi Pariwisata Sumatera Utara(http://m.beritasumut.com/ di akses 23 Februari 2017).

Adapun salah satu kegiatannya yaitu mengadakan kegiatan ber-cosplay untuk memeriahkan kegiatan tersebut.Perlombaan ber-cosplay di selenggarakan karena dianggap oleh panitia pelaksana sangat berhubungan dengan kegiatan di kalangan remaja Jepang.Pada tahun pertama, perlombaan yang di selenggarakan sangat sederhana, yaitu seorang cosplayer yang mengikuti perlombaan hanya sekedar melakukan peragaan berjalan di atas panggung, layaknya seorang model. Yang dimana seharusnya makna cosplay itu sendiri berarti nmemperagakan karakter tokoh anime atau manga dan lainya diiringin musik (sound) atau suara sesuai dengan karakter yang diperankan. Secara sederhana cosplayers membantah bahwa mereka tidak sama dengan model atau aktor. Adapun kegitan dalam perlombaan cosplay di bagi atas dua kategori, yaitu single cosplay dan cosplay cabaret, single cosplay adalah kategori perlombaan cosplay yang diperankan oleh satu orang, sama persis seperti peragaan kostum pada modelmodel. Sedangkan karbet cosplay adalah kategori perlomboaan cosplay yang dilaksanakan secara kelompok, seperti drama, para peserta berperan sesuai skenario drama, awalnya memerankan drama komedi, adapun hasil wawancara dari salah satu seorang cosplayer Misnan atau sering juga di panggil Mise (27):

"Tahun 2008 awalnya saya punya teman yang kuliah di jurusan bahasa Jepang, dan dari dia saya dapat informasi mengenai acara festival Budaya Jepang, awalnya saya hanya liat-liat saja terus di tahun ke dua 
saya mulai ikut ber-cosplay dan perfrom juga di tahun 2009" (Wawancara tanggal 2 Februari 2017)

Sejak perayaan bukansai di tahun pertama, dimana para remaja yang mengenakan kostum cosplay, baik remaja yang mengikuti perlombaan atau sekedar mengenakan kostum saling bertemu, sejak pertemuan tersebut para remaja saling mengenal satu sama lain. Setelah acara bukansai tersebut dan karena memiliki hobi yang sama, para penikmat cosplay mulai membentuk komunitas Cosplay Medan (cosmed) yang terbagi juga beberapa tim yaitu: Zodiart Alliance Assault Team (Z.A.A.T), Be Metamorfosa Family (BMF), Tosca Green, Unlimited, Ciccle Clover.peneliti melakukan wawancara kepada komunitas Cosplay. Seiring waktu berlalu, kegiatan kegiatan cosplay mulai banyak diminati dikalangn remaja di Kota Medan dan berkembang cukup pesat.

Biasanya bila ingin mengetahui mengenai cosplay medan atau menanyakan mengenai cosplay, kelompok akan mendapatkan informasi tersebut melaluli jejaring sosial yakni facebook dengan nama akun Cosplay Medan, melalui grub media sosial ini anggota cosplay mendapatkan informasi-informasi tentang cosplay, baik itu kegiatan acara cosplay, diskusi bagaimana membuat kostum, mempublikasikan foto-foto atau video kegiatan cosplay Medan dan lain sebagainya.

Di tahun 2015 perkembangan cosplay terus meningkat dengan diakannya festival Bunkasai pada tanggal 19-21 Maret 2015. Festival ini merupakan yang ke-7 kalinya dilaksanakan di Universitas Negeri yang ada di Medan (http://aotakeusu.blogspot.co.id/2015/05/bunkasai-usu-2015_10.html 20 April 2017). Perkembangan cosplay di Medan kian menggembiarakan. Admin sosial media Fb cosplay Medan, Motoharu menyebutkan talenta pemeran karakter tokoh anime kian hari kian bertambah. "Sekarang saja sudah ada 2.700 lebih anggota yang bergabung", ungkap Motto dalam press-confrence menyambut event "Battle of Character" yang bakal diadakan pihaknya pada Minggu 25 Oktober 2015 di Amaliun Foodcourt Jalan Amaliun Medan.(http://www.medanbisnisdaily.com 20 April 2017)

Namun pada tahun 2016 terakhir ini perkembangan cosplay dikota Medan dikatakan menurun karena ketidak kompakan antara cosplayer satu dengan yang lainnya. Hal ini menimbulkan sikap kecemburuan sosial yang akibatnya menganggu jalannya perkembangan cosplay. Menurut hasil penelitian yang dilakukan peneliti dari hasil wawancara bersama Mise (27) ia menceritakan: 
"Perkembangan cosplay untuk sekarang sangat memprihatinkan banyak drama antar sesama cosplayer itu sendiri, mereka saling menjatuhkan padahal dalam satu komunitas bahkan tim, penyebabnya sendiri ialah kecemburuan sosial dari segi kostum, uang. Anggota baru pun kurang sosialnya, umunya lebih sering senior yang menyapa juniornya duluan bisa juga di bilang lebih ke individu."(Wawancara tanggal 2 Februari 2017)

Selain itu, perkembangan cosplay yang menurun diakibatkan kurangnya pengadaan event yang menjadi wadah untuk cosplayer dalam menunjukkan bakatnya. Seperti yang dijelaskan oleh "Isan salah seorang cosplayer Medan ia menjelaskan awalnya cosmed banyak yang ikut perfrom dan memiliki sistem penjurian yang bagus, namun untuk sekarang beberapa tahun belakngan event sendiri sudah mulai kurang disebabkan saat adanya event, penyelenggara bertujuan untuk semua cosplayer yang hadir untuk ikut perfrom dan meramaikan acara. Namun hanya sebagian saja yang perfrom, sisanya hanya datang untuk berfoto-foto saja sehingga panitia malas untuk buat acara.

\section{Peniruan Cosplayer Terhadap Tokoh Anime}

Cosplayer adalah orang yang menekuni hobi seni yang menirukan karakter fantasy. Cosplayer itu ruang lingkupnya meliputi, keterlibatan penciptaan kostum, makeup, peniruan ekspresi (mimic), bahasa tubuh (body languange), peiruan perilaku (akting), dan mengerti profile desain karakter (asal usul, tempat, sejarah) (http://www.facebook.com/Cosplay Indonesia/posts.html 15 Febuari 2017).

Cosplay (Costume Play) yang berarti bermain kostum, cosplay berm arti hobi mengenakan pakaian beserta aksesories dan rias ajah seperti yang dikenakan oleh tokoh-tokoh karakter dari animeataupunmanga, seorang cosplayer saat memerankan karakter yang diperankan mulai dari rias wajah (make-up), aksesories, kostum yang digunakan. Mimikri dalam studi poskolonialisme dan secara khusus dalam pandangan Bhabha (1994) adalah "reproduksi belang-belang subjektivitas eropa di lingkungan kolonial yang sudah "tidak murni", tergeser dari asal-usulnya dan terkonfigurasi ulang dalam cahaya sensibilitas dan kegelisahan kolonialisme dan menjelaskan bahwa operasi mimikri tersebut yang dilakukan oleh pihak penjajah maupun terjajah, menghasilkan efek-efek yang ambigu dan kontradiktif dengan 
demikian, dapat dikatakan bahwa hasil dari mimikri selalu "hampir serupa tapi tetap tidak sama".

Mimikri berarti menirukan berarti dapat disimpulkan bahwa cosplayer menirukan tokoh anime ataupun karakter fantasy yang disukainya. Mulai dari segi kostum, makeup, peniruan ekspresi (mimic), bahasa tubuh (body languange), peiruan perilaku (akting), dan menegerti profile desain karakter (asal usul, tempat, sejarah). Dari segi mendapatkan kostum cosplayer awalnya membeli kostum tetapi lama kelamaan belajar membuat kostum sendiri. Berdasarkan hasil wawancara dengan Septian

Pertama kali membeli kostum, namun setelah sharing-sharing sama temen dari hal mendapatkan bahan, sampe cara pembuatannya lalu mencoba untuk membuat sendiri dan berhasil, jadi sampe sekarang buat kostum sendiri, dari sekedar buat kostum sekarang sudah jadi buka usaha kostum sendiri"(Wawancara tanggal 5 Februari 2017)

Kemudian dari hasil wawancara yang peneliti dapatkan, dalam segi kostum cosplayer hanya memakai kostum cosplay pada saat event dan kerja. Kemudian dalam kegiatan sehari-hari cosplayer hanya memakai kaos atau aksesoris yang bertemakan anime. Berdasarkan wawancara dengan Audo (23):

"Kalau untuk kegiatan sehari-hari hanya memakia kaos yang ada gambar animenya, tetapi kalau kostumnya dipakai hanya saat dievent ataupun kerja."(Wawancara tanggal 5 Februari 2017)

Namun tidak sampai disitu saja, saat seorang cosplayer memerankan tokoh AnimeatauMangaia harus benar-benar mendalami karakter yang ia perankan tidak hanya dari segi kostum ataupun aksesoris tokoh anime tersebut seorang cosplayer harus mendalami dan menjiwai karakter yang ia perankan. Seperti halnya penjelasan Isan (23) mengenai pendalam karakter saat cosplay

"Isan menjelaskan pendalaman karakter itu tergantumg individu ada yang hanya untuk fun aja, untuk memamerkan kostum, ada juga hanya untuk meramaikan acara saja namun bagi yang serius saat perform, tidak sembarangan harus menampilkan semirip mungkin mulai dari kostum, aksesoris yang digunakan, gerak-gerik tubuh bahkan sampai dengan gaya bicaranya."(Wawancara tanggal 2 Februari 2017). 
Seperti halnya saat seorang cosplayer memerankan tokoh "Sasuke Uciha" dari "Naruto" yang mempunyai sifat pendiam dan stay cool maka seorang cosplayer yang memerankannya harus bersifat demikian. Jika seorang cosplayer tidak menghayati perannya seperti tokoh Anime Sasuke, maka tidak maksimal dalam memerankan tokoh cosplay tersebut. Berdasarkan wawancara dengan Darin Lutfi (23)

"Saat memakai kostum mengahyati kostum apa yang dipakai, misalnya tokoh Powerangers jadi saat mmemakai kostum Powerangers saya berperilaku seperti Powerangers".(Wawancara tanggal 5 Februari 2017)

Kemudian dari segi gaya bicara, para cosplayer kebanyakan saat pertama kali mengikuti cosplay terikut dengan gaya bicara tokoh cosplay tetapi lama kelamaan cosplayer dapat membedakan gaya bicara mana yang dipakai saat bercosplay dan gaya bicara yang dipakai saat event. Berdasarkan wawancara dengan Emilia Kamil (19)

"Dulu saat pertama kali ikut cosplay, kalau ngumpul bareng anak cosplay saat ngomong gaya bicaranya terikut dengan tokoh cosplay yg sering diperankan, tapi sekarang semakin dewasa ya udah mulai bisa bedain saat ber-cosplay dan saat sehari-hari"(Wawancara tanggal 9 Februari 2017)

Berdasarkan wawancara tersebut terlihat bahwa pemakaian kostum cosplay hanya dipakai disaat event atau kerja kemudian dalam kegiatan sehari-hari para cosplayer hanya memakai kaos yang bergambarkan anime jadi pemakaian kostum cosplay tidak dipakai setiap hari.

\section{Ongkos Sosial Mengikuti Kegiatan cosplay}

Ongkos Sosial dalam istilahsosiologi berarti biaya yang dikeluarkan untuk membayar segala manifestasi gayahidup seperti halnyafashion, selera makan, pilihan untuk bertempat tinggal, cara mengonsumsi sesuatu dan lain sebagainya (Redana, dalam Meirisyah Eldinah 2012). Dalam pernyataan tersebut tersirat makna bahwa orang rela membayar,mengongkosi begitu mahal untuk kepentingan citra dari barang yang digunakan. Artinya membeliatau menggunakan sesuatu barang bukan berdasarkan kebutuhan (need) tetapi keinginan (wants).

Dalam konsep pemahaman cosplayers, keinginan (wants) yang dimaksud adalah mencari kesenangan dan kenyamanan yang dianggap sebagai identitas diri.Ongkos sosoial dalam kategori yang dimaksud juga berupa biaya yang dihabiskan untuk membuat rangkaian kostum pada sebuah 
karakter. Namun demikian, pada dasarnya yang mengikuti copslay sebagaian besar adalah remaaja danmasih bergantung dari uang pemberian orang tua, sehingga beberapa cosplayer ini menggunakan prinsip ekonomi , yaitu dengan modal sekecil-kecilnya menghasilkan untung yang sebsarbesarnya.

Namun demikian, hal tersebut tidaklah mutlak. Beberapa cosplayer memang menggunakan modal yag sekecil-kecilnya, tetapi tidak mengambil untung yang besar mengingat pembelinya adalah sesama cosplayer juga. Sehingga para cosplayer mengeluarkan biaya tidak terlalu mahal dan mendapatkan hasil yg bagus. Berdasarkan hasil wawancara dengan Darin Lutfi (23) diuraikan bahwa:

"Kalau pembuatan kostum kalau bahan busa biasanya dibuat sendiri tetapi kalau pembuatan kostum yg rumit biasanya dipesen kemaker, biaya paling standar untuk pembuatan satu kostum berkisar Rp. 500.000 itu sudah biaya paling murah."(Wawancara tanggal 5 Februari 2017)

Selain mendapatkan kostum dengan harga murah, salah seorang cosplayer mengaku mempunyai kostum dengan harga yg mahal pula. Berdasarkan hasil wawancara dengan Zulhijriyansyah (23):

"Kalau kostum Kamen Rider agak mahal karena ada lapisan kulit imitasi jadi harganya berkisar Rp 2.500.000 sudah full set."(Wawancara tanggal 5 Februari 2017)

Hal ini berarti setiap kostum anime/manga berbeda biaya yang dibutuhkan dalam pembuatan ataupun pembeliannya sesuai dengan tinngkat kerumitan dan detail kostum.. Berdasarkan hasil wawancara dari Isan (23):

"Kalau biaya kostum tergantung tingkat kesulitan dan detail contohnya kostum Ranger sekitar Rp. 1.000.000 itupun tergantung bahan apa yg dipakai dan detail dari kostumnya."(Wawancara tanggal 2 Februari 2017)

Bercosplay berarti menirukan tokoh anime/manga yang disukai termasuk dalam segi kostum.Hal ini berarti seorang cosplayer dituntut untuk mempunyai kostum anime/manga yang disukai.Dari sekedar membeli kostum lama kelamaan seorang cosplayer pandai untuk membuat kostum bahkan sudah membuka usaha pembuatan kostum. Berdasarkan hasil wawancara dengan Septian (23): 
"Pertama kali membeli kostum, namun setelah sharing-sharing sama temen dari hal mendapatkan bahan, sampe cara pembuatannya lalu mencoba untuk membuat sendiri dan berhasil, jadi sampe sekarang buat kostum sendiri, dari sekedar buat kostum sekarang sudah jadi buka usaha kostum sendiri."(Wawancara tanggal 5 Februari 2017)

Hal yang serupa juga diungkapkan oleh Mise yang merupakan CEO(Chief Executive Officer)dari komunitas cosplay dan juga merupakan maker pembuatan kostum cosplay. Berdasarkan hasil wawancara dengan Mise (27):

"Kebetulan saya maker, ya saya membuat sendiri kostum tetapi kalau bagian kaos daleman saya pesan."(Wawancara tanggal 2 Februari 2017)

Anggota cosplayer selain dapat membuat kostum, hobi cosplay ini juga dimanfaat sebagai ajang pekerjaan. Karena dengan memakai kostum cosplay dapat membuat kertarikan sendiri bagi peminatnya. Berdasarkan hasil wawancara dengan Septian (23):

"Saya memakai kostum cosplay selain pada saat event, juga pada saat ada panggilan kerja misalnya diundang untuk meramaikan acara."(Wawancara tanggal 5 Februari 2017)

Dari wawancara tersebut dapat disimpulkan dengan menekuni hobi sebagai cosplayer, selain membanggakan karena dapat terlihat beda juga dapat mengasah kreatifitas kemudian dari hasil kreatifitas tersebut dapat menghasilkan uang.

\section{Nilai dan Norma dalam Cosplay}

Untuk beberapa masyarakat umum mungkin saja menilai cosplay sebagai suatuhal yang aneh karena menampilkan busana yang tidak biasa, hanya menghabiskanuang karena harus menyiapkan kostum dan properti pendukung lain, dan bahkan adayang mengatakan bahwa seseorang yang melakukan cosplay dianggap sebagaiseorang yang krisis identitas. Namun menurut orang yang memang senang dengancosplay menilai ini adalah aktivitas positif yang bisa memberikan mereka kepuasandiri dan kepuasan bersama anggota lainnya serta memberikan keterampilanketerampilanyang didapatkan selama melakukan cosplay Setiap masyarakat memiliki serangkaian nilai (values) dan norma (norms). Apa yang disebut nilai adalah preferensi masyarakat atas yang baik dan yang buruk; yang benar dan yang salah; yang dapat diinginkan dan yang tidak dapat diinginkan. Sebagai 
bagian dari budaya, nilai mempengaruhi perilaku, emosi, dan pemikiran. Nilai penting norma pun beragam.Norma yang terpenting adalah apa yang disebut sebagai “tabu”(Pals, Daniel L. 2011 :99).

Keluarga adalah unit terkecil dari masyarakat yang terdiri atas kepala keluarga beberapa orang yang berkumpul dan tinggal disuatu tempat dibawah suatu atap dalam keadaan saling ketergantungan.Peranan keluarga menggambarkan seperangkat perilaku antar pribadi, sifat, kegiatan yang berhubungan dengan pribadi dalam posisi dan situasi tertentu.Oleh karena itu pandangan keluarga sangat berpengaruh dalam perkembangan anggota cosplayer. Jika keluarga mendukung dalam menekuni hobi bercosplay maka cosplayerakan lebih termotivasi dalam menekuni hobinya sebaliknya jika keluarga melarang anggota cosplay untuk menekuni hobinya yaitu bercosplay maka terhentilah hobi bercosplay tersebut. Tetapi kenyataannya tidak semua anggota keluarga menerima untuk menekuni hobi bercosplay karena sebagaian besar orang tua menganggap hobi bercosplay itu aneh dan tidak ada manfaatnya. Berdasarkan hasil wawancara dengan Rizki Fachrozi(19)

"Awalnya keluarga tidak mendukung untuk menekuni hobi bercosplay, bahkan kostum cosplay yang saya punya hampir mau dibakar dan dibuang oleh mama."(Wawancara tanggal 4 Februari 2017)

Hal ini berarti setiap anggota cosplay harus bersusah payah meyakinkan keluarga bahwa hobi bercosplay itu keren dan bermanfaat. Tetapi seiring berjalannya waktu setelah keluarga megetahui perkembangan positif dalam menekuni hobi bercosplay, keluarga mulai mendukung untuk menekuninya. Berdasarkan hasil wawancara dengan Zulhijriyansyah (19):

"Awal menekuni cosplay ini orang tua bilang buat apa ikut bercosplay dan membuat kostum cosplay karena kalau salah dalam membuat kostum hanya menimbulkan sampah dan bisa membuat kuliah terganggu tetapi dari iku-ikut cosplay ini menjadi lahan untuk mendapatkan uang sehingga tidak tergantung ke orang tua dan akhirnya orang tua setuju dan mendukung."(Wawancara tanggal 4 Februari 2017)

Hal yang serupa juga dikatakan oleh Darin Lutfi (23):

"Pandangan keluarga saat pertama kali ikut cosplay tidak didukung karena orang tua berpandangan aneh dengan kostum cosplay tetapi karena tidak berpengaruh dengan kuliah dan dari cosplay ini dapat 
mengasilkan uang jadi sekarang didukung."(Wawancara tanggal 5 Februari 2017)

Tetapi ada juga keluarga yang mndukung untuk menekuni hobi bercosplay Emelia Kamil (19):

Kalau dari pihak bunda dukung malah dan bunda selalu hadir ketika saya lagi perfrom, dari pihak abang yang sempat ga dukung namun setelah dilihatnya kami mulai menghasilkan dri cosplay ini, sekarang mereka emang sangat mendukung"(Wawancara tanggal 9 Februari 2017)

Selain dari sisi keluarga, ternyata cosplayer juga mendapat hambatan dari segi masyarakat. Pandangan masyarakat yang tidak mengerti cosplay menganggap bahwa hobi bercosplay itu aneh. Berdasarkan hasil wawancara dengan Mise (27):

"Kalau dilingkungan masyarakat yang tidak mengerti cosplay terutama tetangga, mereka mengganggap hobi cosplay ini aneh bahkan kalau lagi bikin kostum dirumah aku dibilang om robot"(Wawancara tanggal 2 Februari 2017)

Audo menambahkan " pernah dianggap aneh, jadi saat membicarakan cosplay saat nongkrong dengen temen yang tidak mengerti cosplay jadi lain tatapannya" Berdasarkan hasil wawancara diatas terlihat bahwa saat pertama kali mengikuti cosplay banyak hambatan mulai dari segi keluarga sampai masyarakat tetapi dengan kritikan tersebut dapat membangun mental cosplayer untuk menjadi seorang cosplay yang sesungguhnya.

Didalam bercosplay tidak jarang cosplayer menggunakan kostum yang tidak sesuai dengan gender, misalnya kostum laki-laki dipakai oleh perempuan dan sebaliknya kostum perempuan dipakai oleh laki-laki. Kategori ini disebut kategori cosplayers berdasarkan pertukaran peran atau dalam istilah cosplay disebut crossdress.Sedangkan cosplayer yang berperan sebagai lawan jenis disebut crossplay. Berdasarkan hasil wawancara dengan Rizki Fachrozi (19)

"Pernah memakai kostum poweranger cewek, powerangerskan tidak menampakan muka dan kebeulan badan saya kurus jadi kelihatan seperti cewek"(Wawancara tanggal 4 Februari 2017)

Dari wawancara diatas terlihat bahawa Rizki Fachrozi adalah bergender laki-laki tetapi memakai kostum cosplay yang bergender perempuan. Selain 
Rizki Fachrozi, ada juga serorang cosplayers cewek yang memakai kostum cowok dan harus berperilaku seperti cowok yaitu Emilia Kamil. Berdasarkan hasil wawancara dengan Emilia Kamil (19):

"ia merasa bangga ketika saat dia memakai kostum anime lelaki tpi dia di sapa "bang" dan di puji oleh orang kalau dia cocok dengan kostum tersebut dia juga merasa sudah totalitas"(Wawancara tanggal 9 Februari 2017)

Berdasarkan wawancara tersebut terlihat bahwa bercosplay berarti harus total dalam memerankan tokoh cosplay walaupun itu harus memakai kostum yang tidak sesuai dengan gender. Karena bercosplay itu berarti unik, sebab kostum yang digunakan berbeda dengan jenis hobi yang lainnya, dimana penggunaanyapun tidak setiap hari.Oleh sebab itu, bercosplay terlihat mahal dan istimewa.

\section{Penutup}

Perkembangan cosplay di Kota Medan khususnya dikalangan remaja sudah tidak asing lagi, di mana sebelumnya, para remaja yang ada di Kota Medan mengenal cosplay melalui berbagai media, baik majalah-majalah, televisi, internet, maupun dari berbagai media sosial lainya. Awalnya mulanya cosplay di kenal dikalangan remaja Medan melalui kegiatan Bukansai, yang di selenggarakan oleh mahasiswa Jurusan Sastra Jepang Universitas Sumatera Utara dalam pelaksanaan kegiatan tahunan "Festival Budaya Jepang" (Bukansai) pada tahun 2008. Adapun salah satu kegiatannya yaitu mengadakan kegiatan ber-cosplay untuk memeriahkan kegiatan tersebut.Perlombaan ber-cosplay di selenggarakan karena dianggap oleh panitia pelaksana sangat berhubungan dengan kegiatan di kalangan remaja Jepang. Pada tahun pertama, perlombaan yang di selenggarakan sangat sederhana, yaitu seorang cosplayer yang mengikuti perlombaan hanya sekedar melakukan peragaan berjalan di atas panggung, layaknya seorang model.. Selain itu seorang cosplayer dalam memerankan tokoh yang diperankan sangat mengahyati perannya terutama pada saat mengikuti perlombaan baik dari segi riasan wajah sampai kostum yang di gunakan, adapun kostum yang di tempah oleh makeer sampai membuat kostum sendiri, tidak hanya sampai di situ seorang cosplayer juga menirukan gerak tubuh dari karakter yang mereka perankan. Terbukti dari prestasi yang mereka dapat dari berbagai event, tetapi peniruan tokoh cosplay hanya dilakukan disaat ada event saja dan untuk sehari-hari seorang cosplayer 
tidak memakai kostum cosplay melaikan hanya memakai kaos yang bertemakan anime.

\section{Daftar Pustaka}

\section{Buku}

Bhabha, Hami K. 1994, Location of Culture, London and Newyork. Routledge.

Bungin, Burhan. 2001, Metodologi Penelitian Sosial, Surabaya: Air Langga University Press

James Danandjaya. 1991, Foklor Indonesia Ilmu Gosip, Dongeng, dan lainlain. Jakarta: PT. Temprint

Koentjaraningrat. 1990, Sejarah Teori Antropologi II, Jakarta. UI Press.

Koentjaraningrat. 2002, Pengantar IImu Antropologi , Jakarta. PT. Rineka Cipta.

Koentjaraningrat. 2009, Pengantar IImu Antropologi, Jakarta. PT. Rineka Cipta.

Marzali Amri. 2012, Antropologi \& Kebijakan Publik, Jakarta. PT. Kencana. Moleong, L.J. 2001, Metodologi Penelitian Kualitatif. Bandung: PT. Remaja Rosdakarya.

Redena, Bre. Ongkos sosial Gaya Hidup Mutakhir. Dalam Ibrahim, Idi Subandy, Lifestyle Ectasy: Kebudayaan Pop dalam Masyarakat Komuditas Indonesia. Yogyakarta: Jalasutra

Skripsi dan Refrensi:

Aisyah, Karina. 2012, "Rasa Memiliki dalam Komunitas Cosplay ", Skripsi, Depok: Universitas Indonesia.

Barimbing, Yustina. 2012, " Cosplay Jepang Nihon No Kosupure ”, Skripsi, Medan: Universitas Sumatera Utara.

Eldinah, Meirisyah. 2012, "Profil tiga Cosplayer Sebagai Pembentuk Identitas diri Remaja", Skripsi, Medan: Universitas Negri Medan.

Pratiwi, Sukma Riatifani. 2012, "Faktor Penyebab Perilaku Cosplayer LARP ( Live Action Role Playing) Anime Pada Komunitas JCEB ( Japanese Club East

Borneo ) Samarinda", Program Studi Psikologi Fakultas IImu Sosial dan IImu Politik Universitas Mulawarman.

Tanjung, Arianda. 2016, " Te r u s b e ra kt if it a s t a n pahe n t i Ko m u n it a s C o s p I a y Medan", Waspada, terbit 31 Juli 2016 
Internet:

https://id.wikipedia.org/wiki/Anime

https://id.wikipedia.org/wiki/Manga

https://id.wikipedia.org/wiki/Kota_Medan 